\title{
هيئة المكمينه
}

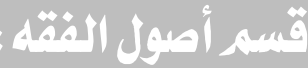

أسـتاذ أصـول الفقـهـ المتفــرغ بكليـة الشـريعة

أ.د/ حمدي صبع طه

والقــانون بالقـاهرة وعضــو اللجنـة العلميــة وعضو هيئة كبار العلماء.

أستاذ أصسول الفقه بكلية الشـريعة بجامعة أم

أ.د/ حمزة بن حسيز بن حمزة الفعر

القرى وعميد معهد البحوث العلميـة بكلية

الشـيعة بمكـة المكرمـة وعضـو مجمع الفقـه

برابطة العالم الإسالامي.

أسـتاذ أصـول الفقـه المتفـرغ بكليـة الشـريعة

أ.د/ رمضان محمل عيل هتيمي

والقـانون بالقـاهرة وعميـدها الأسـبق وعضسو

اللجنة العلمية.

أسـتاذ أصـول الفقـه وعميــ كليـة الدراسـات

أ.د/ سعود بن إبراهيه الشريم

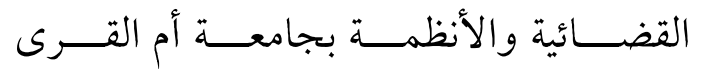

بالسعودية وإمام الحرم المكي

أسـتاذ أصسول الفقـهـ المتفـرغ بكليـة الشـريعة

أ.د/ عبد الحي عزب عبد العال

والقــانون بالقـاهرة وعضـــو اللجنــة العلميـة

ورئيس جامعة الأزهر سابقا

(*) ترتيب أسماء السادة الأساتذة أعضاء هيئة المحكمين وفق ترتيب حروف الهجاء. 
أسـتاذ أصسول الفقـه بكليـة الشـريعة والقـانون أ.د / علي حسيز علي عبد النبي بالقـاهرة ووكيـل كليـة الثــريعة والقــانون بالقاهرة

أستاذ أصـول الفقـه بكلية الشـريعة بجامعـة أم أ.د/ علي بن عباس بن عثمان الحكمي القـرى وعميـدها سـابقا وعضـو هيئة كبـار العلماء في المملكة العربية السعودية سـابقًا، وعضـــو المجمــع الفقهـي برابطــة العــالم الإسلامي.

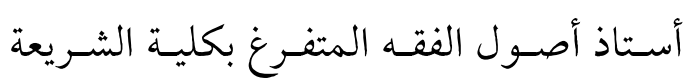
أ.د/ محمد محمل عبد اللطيف والقانون بالقاهرة وعضو لجنة المحكمين. أسـتاذ أصـول الفقـه بكليـة الشـريعة والقـانون أ.د/ محمود عبل الرحمن عبد المنعه بالقاهرة وعضو لجنة المحكمين ورئيس قسم أصول الفقه بشريعة القاهرة السابق

أسـتاذ الفقـه المتفـرغ بكليـة الشـريعة والقـانون أ.د / أسامة محمد حسز العبل بالقاهرة وعضو اللجنة العلمية ورئيس جامعة الأزهر سـابقا ورئيس اللجنة الدينية بمجلس

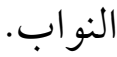

أستاذ الفقه بكلية الشـريعة والقـانون بالقـاهرة أ.د د/ حسن صلاح الصغير

وعضو لجنة المحكمين وأمين عام هيئة كبار

العلمـاء ورئيس الأكاديميـة العالميـة لتـدريب الوعاظ وباحثي الفتوى بالأزهر الشريف. 
أستاذ الفقـه المتفـرغ بكليـة الشـريعة والقـانون

$$
\text { بأسيو ط. }
$$

أستاذ الفقه المتفرغ بكلية الشـريعة والقانون أ.د/ عبد العزيز عطا سيل أحمد بالقـاهرة، ووكيل الكليـة سـابقا وعضـو لجنـة المحكمين.

أستاذ الشريعة الإسلامية ووكيل كلية الحقوق أ.د/ عبد المنعم أحمد سلطان عيل جامعة المنوفية.

أسـتاذ الشـريعة الإســلامية بكليـة دار العلـوم جامعة القاهرة

أستاذ الفقه المتفرغ بكلية الشريعة والقانون أ.د/ علي محمد منصور عليوة بالقـاهرة ورئسيس قســم الفقـهـ سـابقا وعضـو اللجنة العلمية.

أستاذ الفقه المتفرغ بكلية الشريعة والقانون أ.د/ فتحي عثمان عمر الفقي بالقـاهرة ووكيل الكلية سـابقا وعضو اللجنة العلمية وعضو هيئة كبار العلماء.

أستاذ الفقه المتفرغ بكلية الشـريعة والقانون أ.د / فرحات عبد العاطي سعل

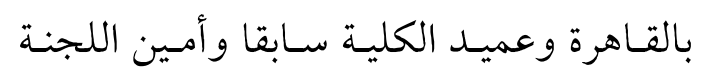
العلمية. أستاذ الفقهـ بكلية الشـريعة والقـانون بالقـاهرة أ.د / محمد أبوزيل الأمير ونائب رئيس جامعـة الأزهر للوجـه البحري والمنسق العام لبيت العائلة المصرية وعضو

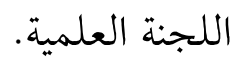


أستـاذ الفقـه المتفـرغ بكليـة الشـريعة والقـانون

أ .د / محمد راشد علي أبوزيل

بالقاهرة وعضو لجنة المحكمين.

أستاذ الفقـه المتفرغ بكلية الشـريعة والقـانون

أ.د / محمد عبد الستار الجبالي

بالقـاهرة ورئسيس قسـم الفقـه سـابقا وعضـو

لجنة المحكمين.

أسـتاذ الشــريعة الإســامية بكليـة الحقـوق

أ. د/ محمل عبد المنعم حبشي

جامعة عين شمس.

أسـتاذ الشــريعة الإســلامية بكليـة الحقـوق

أ. د / محمد ذجيب عوضيز

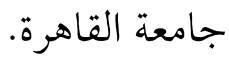

أسـتاذ الفقـه المتفـرغ بكليـة الشـريعة والقـانون

أ .د/:نصر فريل محمل واصل

بالقـاهرة ومقـرر اللجنـة العلميـة وعضـو هيئة

كبار العلماء ومفتي الديار المصرية سابقا.

أسـتاذ الفقـه المتفــرغ بكليـة الشـريعة والقـانون

أ.دد/ نوبي محمل جاد الكريم

بالقاهرة وعضو لجنة المحكمين.

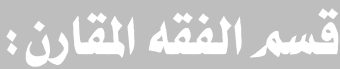

أستـاذ الفقـه المقـارن المتفـرغ بكليـة الشـريعة

أ.د/ أحمل علي طه ريان

والقـانون بالقــاهرة وعميـــ كليـة الشـــيعة

والقانون بأسيوط سابقا وعضو اللجنة العلمية

وعضو هيئة كبار العلماء

أستاذ الفقه المقارن بكلية الشريعة والقانون

أ.دد/ أسامة عبل السميع محمدل

بالقاهرة ووكيل الكلية سابقا 
أسـتاذ الفقـه المقــارن المتفـرغ بكليـة الشـريعة

أ.د أرشاد حسن خليل

والقانون بالقاهرة وعميد الكلية سابقا ومقرر

اللجنة العلمية

أسـتاذ الفقـهـ المقـارن المتفـرغ بكليـة البــات

أ.د/ سعاد الشرباصي حسنيز

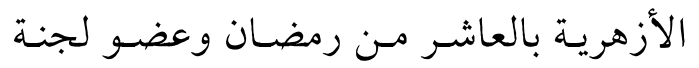

المحكمين

أستـاذ الفقـه المقــارن المتفـرغ بكليـة الثـريعة

أ.د / سعد اللدين مسعد هلالي

والقـانون بالقـاهرة وعميـــ كليـة الدراسـات

الإسلامية والعربية بدمياط وأسوان سابقا

أسـتاذ الفقـه المقــارن المتفــرغ بكليـة الشـريعة

أ. د/ سيف رجب قززامل

والقانون بطنطا وعميد كلية الشريعة والقانون

بطنطا سابقا وعضو اللجنة العلمية

أسـتاذ ورئسيس قســم الفقـهـ المقــارن بكليـة

أ.د ع عبد المزيز فز محمد

الشريعة والقانون بالقاهرة

أستاذ الفقه المقارن بكلية الشـريعة والقـانون

أ.د/ عبد الغني عبد الفتاح غنيه

بالقاهرة

أستاذ الفقـه المقارن بكلية الشـيعة والقـانون

أ.د / عطا عبد العاطي السنباطي

بالقاهرة وعميد كلية الدراسات العليا بجامعة

$$
\text { الأزهر سابقا }
$$

أستاذ الفقه المقارن بكلية الشـريعة والقانون

أ.د / محمل عبل الرحمن الضويني

بالقـاهرة ووكيل الكلية سـابقا ووكيل الأزهـر

الشريف 
أستاذ القانون المدني المتفرغ بكلية الحقوق أ.د / أحمد عبد العال أبو قرين جامعة عين شمس ادس العن المس

أستاذ القانون الدولي الخاص المتفرغ بكلية أ.د/ أحمل عبد الكريم محمد سلامة الحقوق جامعة حلوان ونائب رئيس جامعة المئس حلوان الأسبق

أسـتاذ القـانون التجـارى والبحــى والجـوى أ.د/ جمال محمود عبد العزيز بكلية الحقوق جامعة القاهرة ، ومدير مركز

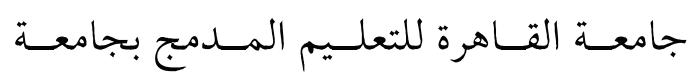
القاهرة

أســتاذ قــانون المرافعــات المتفــــ بكليــة أ.د/ حامل محمد عبد الرحمن أبو طالب

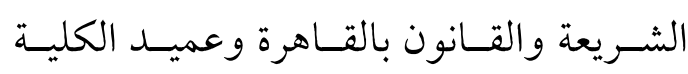
سابقا وعضو اللجنة العلمية

أستاذ القانون المدني بكلية الحقوق جامعة

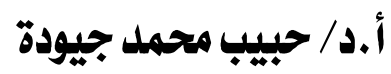
طر ابلس بليبيا أسـتاذ القـانون المــني ووكيـل كليـة الشـريعة أ.د / حمدي سعد أحمد والقانون بطنطا

أستاذ القـانون التجـاري ورئيس قسم القـانون أ.د/ ذكري عبد الرازق محمد خليفة الخاص بكلية الشريعة والقانون بالقاهرة 
أسـتاذ القـانون المــني المتفــرغ بكليـة الشـريعة

أ.د / عبد الخالق حسن أحمد و القانون بالقاهرة

أستاذ الأنظمة بالمعهد العالي للقضاء بجامعة سمو الأمير أ.د/ عبد العزيز بن سطاه الإمام محمد بن سعود الإسلامية بالسعودية ابن عبد العزيز أستاذ القانون المدني المتفرغ بكلية الشريعة أ.د/ عبل الله مبروك محمد النجار

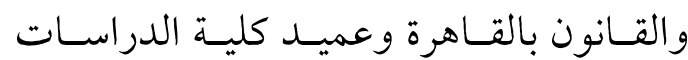
العليا بجامعة الأزهر وعضو اللجنة العلمية وعمل كلية الكرات

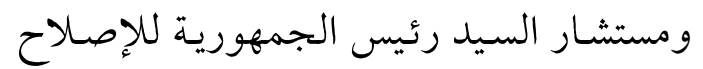
التشريعي

أستاذ القانون المدني المتفرغ بكلية الشريعة أ.د/ محمد علي عثمان الفقي والقانون بالقاهرة

أ.د/ مصطفى محمدل مصطفى الباز أستاذ القـانون الـدولي الخـاص بكلية الشـريعة والقانون بالقاهرة ووكيل الكلية لشئون التعليم

أستاذ القانون الخـاص المتفرغ بكلية الشريعة أ.د/ مصطفى محمد مصطفى عرجاوي والقانون بالقاهرة وعميد كلية الشريعة والقانون بدمنهور سابقا وعضو اللجنة العلمية

أستاذ القانون المـدني بكلية الشـريعة والقانون أ.د/ ممدوح محمد علي مبروك بالقاهرة وعميد الكلية

أستاذ القانون التجاري بكلية الشريعة والقانون أ.د وليل علي محمد علي

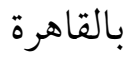


أسـتاذ القــانون التجــاري بالمعهــــــــالي

أ.د ديوسف بن محمد الخضير

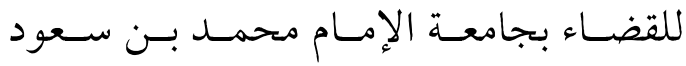

الإسلامية بالسعودية

أستاذ القانون الجنائي بكلية الشريعة والقانون أ.د/ أحمل حسني طه

تفهينا الأشـراف ونائب رئيس جامعـة الأزهـر

سابقا وعضو اللجنة العلمية

أسـتاذ القـانون الإداري بقسـم القـانون العـام

أ.د/ السيل أحمد محمد مرجان

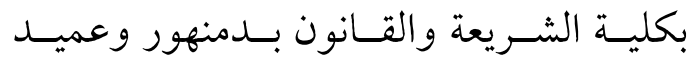

الكلية

أسـتاذ ورئـــس قســـم الاقتصــاد السياسـى

أ.د / السيل عطية عبد الواحل

والماليـة العامـة بكليـة الحقـوق جامعـة عـين

شمس

أستـاذ القـانون الجنائي وعميـد كليـة الحقـوق

أ.د د/ جلال الدين باذجا أحمد

بجامعة شندي بالسودان

أسـتاذ ورئـيس قســم القـانون العـام بكليـة

أ.د / سامح السيد أحمد إبراهيه جاد

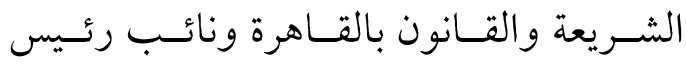

جامعة الأزهر سابقا وعضو اللجنة العلمية

أستـاذ القـانون الجنـائي بقســم القـانون العـام

أ.د عادل عبد العال إبراهيه

بكليـة الشـريعة والقـانون بالقـاهرة وعميـدها

السابق 
أستاذ القانون الإداري المتفرغ بكلية الشريعة

أ. أد / فؤاد محمد النادي

والقــانون بالقــاهرة وعضــو اللجنـة العلميـة

والمستشـار القـانوني لـرئيس جامعـة الأزهـر

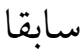

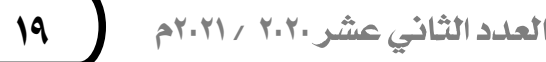


